\title{
Chapter 1 Scope and Objective of This Study
}

This study was commissioned by the Swiss Confederation's State Secretariat for Economic Affairs (SECO) to the Geneva Center for International Dispute Settlement (CIDS). Its objective is to examine the interactions between national courts and international tribunals in the area of investment law. While most international investment agreements (IIAs) ${ }^{1}$ currently provide for investment arbitration as the forum for the resolution of disputes between foreign investors and host States, national courts ${ }^{2}$ also have jurisdiction over certain matters involving cross-border investments. This study seeks to map the relationship between national courts and international investment tribunals in the existing IIA context and examine the possible role of domestic courts in future treaty framework(s) which may emerge from the States' current efforts to reform the system.

As a result of the growing criticisms over, and demands for reform of, investorState arbitration by States, international organizations, and civil society, over the past years, States have embarked on a significant process of reflection on the existing investment treaty system and, in particular, the investor-State arbitral mechanism

The authors of this study thank Anna Korshunova, CIDS researcher, for research assistance; Cara North and Christos Stamatis, CIDS researchers, for assistance in finalizing the footnotes; and Erika Hasler, Tabea Seedoch, and Mathew Yarden of the Library Team at Lévy KaufmannKohler for continuous support in locating bibliographic resources. The study is current as of December 2019.

\footnotetext{
${ }^{1}$ The abbreviation "IIA(s)" is used throughout this study to refer to bilateral investment treaties (BITs), bilateral or regional free trade agreements (FTAs) that include foreign investment obligations (typically contained in a standalone chapter), such as the North American Free Trade Agreement (NAFTA), and sectoral treaties, such as the Energy Charter Treaty (ECT), that include investment obligations. The expression "investment treaties" is sometimes used in this book as synonymous to IIAs.

${ }^{2}$ In relation to courts, this study uses the terms "national", "domestic", "local", and "municipal" as synonymous. 
included in IIAs. In July 2017, the debate concerning investment arbitration reached another level when Member States of the United Nations Commission on International Trade Law (UNCITRAL), including Switzerland, entrusted Working Group III (WGIII) with a "broad mandate to work on the possible reform of investor-State dispute settlement". 3

3. As can be observed from the discussions that have taken place in WGIII so far, the criticism over investor-State arbitration has multiple facets and dimensions, which range from the perceived length and costs of investment arbitration proceedings, the structural inadequacy of $a d$ hoc adjudicatory bodies to ensure consistency in the interpretation of legal issues, to the perceived lack of independence and impartiality of the adjudicators, among others. ${ }^{4}$ One of the more fundamental criticisms often voiced against investment arbitration, including in the political discourse, is that national courts are well placed to resolve investment disputes and there is thus no need for foreign investors to be provided with direct access to international tribunals for the settlement of such disputes. Other criticisms go to the possible scope of investment arbitration tribunals' powers and the coordination of their actions with that of national courts. These criticisms raise questions that go to the very justification for current or future dispute settlement regimes. Answering these more fundamental questions may be helpful before the more specific concerns identified with the investment treaty regime are addressed in the ongoing reform efforts. A proper understanding of the role of domestic remedies may also be generally useful if and when States move to design new international dispute settlement frameworks, as the question of their interaction with domestic remedies is also likely to arise.

4. Against that background, this study seeks to carry out an in-depth review of the interactions between national courts and international mechanisms for the settlement of investment disputes, in the various forms in which they can be conceived, which includes not only investment arbitration but also standing adjudicatory bodies, such as an appeal mechanism (AM) and a multilateral investment court (MIC). By presenting a comprehensive overview of the many interactions between investorState dispute settlement and national courts, while at the same time analyzing the possible role which domestic courts may play in the reform scenarios that States and regional organizations are currently considering, this study seeks to add value not

\footnotetext{
${ }^{3}$ See United Nations General Assembly, Report of the United Nations Commission on International Trade Law (Fiftieth Session (3-21 July 2017)), Official Records of the Seventy-second Session, Supplement No. 17 (A/72/17), paras. 263-264.

${ }^{4}$ See for instance, in the UNCITRAL WGIII context, the following UNCITRAL Secretariat papers: Possible reform of investor-State dispute settlement (ISDS) - Note by the Secretariat, A/CN.9/WG.III/ WP.149; Possible reform of investor-State dispute settlement (ISDS) Consistency and related matters - Note by the Secretariat, A/CN.9/WG.III/WP.150; Possible reform of investor-State dispute settlement (ISDS) Ensuring independence and impartiality on the part of arbitrators and decision makers in ISDS - Note by the Secretariat, A/CN.9/WG.III/WP.151; Possible reform of investor-State dispute settlement (ISDS) Arbitrators and decision makers: appointment mechanisms and related issues Note by the Secretariat, A/CN.9/WG.III/WP.152; Possible reform of investor-State dispute settlement (ISDS) Cost and duration - Note by the Secretariat, A/CN.9/WG.III/WP.153.
} 
only to the legal analysis, but also to the policy reflections that are necessarily linked to the ongoing reform initiatives. It is also meant to promote a better understanding of the multiple intersections that exist and are likely to continue to exist between national and international courts in the field of investment protection, and to suggest possible modes for regulating jurisdictional interactions going forward.

The study is organized as follows. After these introductory remarks, Chap. 2 reviews the existing criticism of investor-State dispute settlement in relation to the role of domestic courts (infra at 2.1). Understanding this criticism requires consideration of the historical, economic, and political reasons that underpin the creation of the current investment dispute settlement system (infra at 2.2) and assessing whether those reasons remain valid in today's world (infra at 2.3). Chapter 3 examines the multiple and often complex ways in which the two systems - national judiciary and international tribunals-interact in the existing IIA framework. Chapter 4 then moves to the main reform scenarios which States are currently considering, with a view to analyzing the possible role which national courts could play if investment arbitration is (i) reformed through targeted adjustments, (ii) supplemented with an $\mathrm{AM}$, (iii) replaced with a MIC, or (iv) supplanted by inter-State mechanisms. It will also take account of the scenario where investment arbitration is entirely eliminated without being replaced by an alternative international mechanism, which would result in a system where domestic proceedings operate as the sole forum for the settlement of investment disputes. Chapter 5 sets out the conclusions and recommendations in light of the analysis carried out in the previous sections.

The main points of intersection between domestic courts and international investment tribunals examined in this study touch on issues of jurisdiction, admissibility, merits, and procedure. The questions examined thus cut across almost the entirety of the law of investment protection in both its substantive and procedural aspects, and have given rise to difficulties in their application and often splits in the jurisprudence. Given the breadth of the issues, the study's approach is to focus primarily on State practice as reflected in the conclusion of IIAs and the policy choices underlying the treaty texts. In so doing, it does not limit the examination to IIAs of certain countries or regions, but seeks to provide a global picture of the IIA practice worldwide to the extent relevant to the issue discussed.

This being said, the study devotes special attention to Swiss practice. Switzerland is a party to the ICSID Convention and has concluded over 110 BITs with its trade partners, making it one of the economies with the widest IIA network worldwide. ${ }^{5}$ Swiss BITs have been invoked in at least 20 known investor-State disputes by Swiss

\footnotetext{
${ }^{5}$ See SECO, "Overview of BITs - List of BITs concluded by Switzerland - May 21st 2019", available at https://www.seco.admin.ch/seco/en/home/Aussenwirtschaftspolitik_Wirtschaftliche_ Zusammenarbeit/Wirtschaftsbeziehungen/Internationale_Investitionen/Vertragspolitik_der_

Schweiz/overview-of-bits.html, listing the BITs concluded by Switzerland. See also UNCTAD, International Investment Agreements Navigator, "Switzerland", available at https:// investmentpolicy.unctad.org/international-investment-agreements/countries/203/switzerland. On Switzerland's BIT practice, see generally Schmid (2013), pp. 651-696.
} 
investors. ${ }^{6}$ Furthermore, Switzerland has been traditionally one of the most chosen seats for international arbitration, including (non-ICSID) investment arbitrations, due to, inter alia, the country's reputation for neutrality and stability as well as the legislation's and the judiciary's pro-arbitration approach. In the last few years, there has been an increase in Swiss-seated investment treaty arbitrations, a trend which may well continue especially for intra-EU disputes as a result of the uncertainties arising from the judgment by the Court of Justice of the European Union (CJEU) in Achmea. $^{7}$ An increase of Swiss-seated arbitrations means, in turn, a potentially greater involvement of the Swiss Federal Tribunal with investment matters. ${ }^{8}$

8. Before embarking on the analysis, a point of terminology is in order. The authors of this study are of the view that the term "ISDS" (which is the acronym for "investor-State dispute settlement" and which is often employed in the reform discussions) is imprecise and may have different meanings depending on the context in which it is used. In its colloquial and perhaps most widely used meaning, the term is essentially synonymous with the current investor-State international arbitration system. ${ }^{9}$ Yet, the a-technical formula "investor-State dispute settlement" does not, in its plain meaning, exclude a possibly broader range of dispute settlement mechanisms. First, there is no semantic reason why it could not encompass non-binding methods of dispute settlement between investors and States, such as conciliation, mediation, ombudsman, and so on. Second, even if one were to limit the scope of the term to binding means of dispute resolution, "ISDS" could well encompass settlement methods beyond the current arbitral system, for instance the MIC. In other words, the current use of the term "ISDS" does not make clear what is the defining characteristic of "ISDS" vis-à-vis "other" mechanisms. Is it the investor's standing to bring a claim in its own name against the State (if so, ISDS would include investment arbitration, with or without an AM, MIC, and domestic courts)? Or is it the fact that the dispute resolution method is international as opposed to national? Or is it a combination of both criteria, such that only means of dispute resolution that offer investors direct access to an international forum qualify as ISDS?

9. Absent clarity as to the contours of what constitutes ISDS (and what does not), and in light of the fact that the ongoing reform discussions as well as the present study seek to reflect upon several distinct dispute settlement mechanisms beyond investment arbitration, for the sake of clarity this study will avoid employing the

\footnotetext{
${ }^{6}$ See Scherer and Murphy (2019), pp. 9-26. By contrast, Switzerland has never been a respondent in an investor-State dispute under an IIA. In April 2014, consultations between a foreign investor and Switzerland were commenced under an IIA. However, no arbitration appears to have been started. See Jarrod Hepburn (2015), Uzan family may return to ICSID, as Switzerland reveals details of threatened investor claim, IAReporter, 17 March 2015.

${ }^{7}$ See CJEU C-284/16, Slovak Republic v. Achmea BV, 6 March 2018.

${ }^{8}$ See infra at 3.3 .

${ }^{9}$ This is also the meaning that appears to be given in the UNCITRAL Secretariat papers. See, e.g., UNCITRAL Working Group III, Possible reform of investor-State dispute settlement (ISDS) - Note by the Secretariat, A/CN.9/WG.III/WP.142, paras. 5-7 (describing the "characteristics of the ISDS regime").
} 
term "ISDS" to the extent possible. It will instead refer to the different (binding) methods of investment dispute resolution on the international plane using the following terms, which in the authors' view capture more precisely their defining characteristics:

- "investor-State arbitration" (or "investment arbitration") is used to refer to a dispute resolution mechanism which allows a foreign investor to bring a claim in its own name against the host State before an adjudicatory body in the nature of an arbitral tribunal, for instance ICSID or UNCITRAL arbitration. Although investor-State arbitration may be based on a contract or a domestic law on foreign investment, this study is primarily concerned with arbitrations based on IIAs, i.e. "investment treaty arbitrations";

- "investment arbitration with an AM" (or similar formulations) is used to refer to the traditional arbitration mechanism supplemented with a review mechanism in the form of a standing appellate mechanism ${ }^{10}$;

- "multilateral investment court" or "MIC" is used to refer to a permanent multilateral adjudicatory body for the resolution of investment disputes, in which foreign investors would have standing to bring claims in their own name against host States $^{11}$;

- "State-to-State dispute settlement" (or "SSDS") is used to refer to inter-State mechanisms, routinely included in IIAs and typically in the form of arbitration, for the resolution of disputes on the interpretation and/or application of IIAs.

\section{References}

Scherer M, Murphy L (2019) Inventory of arbitration proceedings based on Swiss bilateral investment treaties (BIT) (Update 2018). ASA Bull 37(1):9-26

Schmid M (2013) Switzerland. In: Brown C (ed) Commentaries on selected model investment treaties. Oxford University Press, pp 651-696

\footnotetext{
${ }^{10}$ An appellate mechanism complementing investor-State arbitration could be bilateral or multilateral. See, for instance, Article 9.23 of the China-Australia FTA (2015), which provides that within 3 years after its date of entry into force the parties to the FTA shall commence negotiations with a view to establishing a bilateral appellate mechanism to review awards on questions of law. For an example of a "rendez-vous" clause concerning a multilateral appellate mechanism, see for instance, U.S. Model BIT (2004), Article 28, para. 10 and Australia-Republic of Korea FTA (2014), Article 11.2, para. 13 and Annex 11-E.

${ }^{11}$ A MIC could be with or without a built-in appellate mechanism. See Gabrielle Kaufmann-Kohler and Michele Potestà (2016), Can the Mauritius Convention serve as a model for the reform of investor-State arbitration in connection with the introduction of a permanent investment tribunal or an appeal mechanism? Analysis and Roadmap, CIDS Report (hereinafter "Gabrielle KaufmannKohler and Michele Potestà (2016), First CIDS Report"), Section V.D.
} 
Open Access This chapter is licensed under the terms of the Creative Commons Attribution 4.0 International License (http://creativecommons.org/licenses/by/4.0/), which permits use, sharing, adaptation, distribution and reproduction in any medium or format, as long as you give appropriate credit to the original author(s) and the source, provide a link to the Creative Commons licence and indicate if changes were made.

The images or other third party material in this chapter are included in the chapter's Creative Commons licence, unless indicated otherwise in a credit line to the material. If material is not included in the chapter's Creative Commons licence and your intended use is not permitted by statutory regulation or exceeds the permitted use, you will need to obtain permission directly from the copyright holder. 